REVIEWED AND AMENDED VERSION TO BE PUBLISHED IN JOURNAL OF LIBRARIANSHIP AND INFORM ATION SCIENCE IN M ARCH 2013, ISSUE 45 (1)

Do librarians have a shared set of values? A comparative study of 36 Codes of Ethics based on Gorman's Enduring Values

Catherine Foster

Doctoral candidate

Department of Computer and Information Sciences,

University of Strathclyde, Glasgow, Scotland

and

David M cM enemy

Department of Computer and Information Sciences,

University of Strathclyde, Glasgow, Scotland 


\section{Do librarians have a shared set of values? A comparative study of 36 Codes of Ethics based on Gorman's Enduring Values}

\section{ABSTRACT}

Thirty-six ethical codes from national professional associations were studied, the aim to test whether librarians have global shared values or if political and cultural contexts have significantly influenced the codes' content. Gorman's 8 core values of stewardship, service, intellectual freedom, rationalism, literacy and learning, equity of access to recorded knowledge and information, privacy and democracy were used as a benchmark. A quantitative analysis was carried out of which values each code contained. The codes were further qualitatively analysed, to examine how each value was expressed.

It was found that on average codes featured 5 of Gorman's 8 values. The most popular values were: Service, Privacy, Equity of Access, Stewardship and Intellectual Freedom. The least popular value was Rationalism, across all codes. Some codes omitted certain values because of their specific focus, such as the Native American code. Codes varied in how values were expressed, for example some codes limited principles by law, while some did not. Expression of Stewardship and Democracy was found to be stronger in countries which have recently experienced conflict or colonialism. The relationship between the profession and the state was another area of variation. Countries in the Asia-Pacific put more emphasis on the power of the state.

Keywords: ethics; library associations; professional values

Using Gorman's Our Enduring Values as a benchmark, this paper aims to determine whether librarianship could be said to have an over-arching set of ethical principles that guide practising professionals across the world. Do the values espoused by Gorman represent a universal set of principles that the entire profession of librarianship can adhere to?

\section{The values of librarianship}

Ethics in librarianship

Despite being a profession that is centuries old, the literature on ethical issues in librarianship is sparse before the 1970s (Hauptman, 1988). Certainly questions remain as to why the library profession did not consider the issue of ethics important enough to consider codifying before the efforts of the American Library Association (ALA) in 1938. In the UK, the Library Association (LA) did not adopt an ethical code until 1983, over 100 years after it was formed as a professional association. There is a school of thought that suggests the complacency of the profession in this regard was based as much on society's ignorance of what librarians actually do as much as a lack of desire to define an ethical benchmark for professionals. Writing in the mid 1980s Lindsey and Prentice suggest that, "The average person is highly unlikely to have given a second - or even a first - thought to the question of the professional ethics of librarians (Lindsey and Prentice, 1985, p.vii).

However, despite the fact that the majority of library associations around the world have no ethical code (Koehler, 2006) the codes that exist play an important part in holding up standards for professionals to adhere to; they are also important for "communicat[ing] a set of values to the wider world" (M cMenemy et al, 2007, p.28). Michael Gorman suggests "there are now more librarians who question what they do - the very underpinnings of their working lives - than ever before" (Gorman, 2000, p.4).

Professionalism and librarianship 
Within librarianship there is a viewpoint that an uncertainty about its status as a profession creates a lack of confidence about the importance and value of its role in society. Usherwood cites a survey by Bourner in 1978 which found that librarians believed that the public ranked librarians alongside bank cashiers and chiropodists as a profession, and furthermore that librarians agreed with this ranking (Usherwood, 1980, p.11). Usherwood also criticized the anti-research attitude in librarianship and recognised that many librarians have accepted the views put forward by writers such as Larson and Brint that "all professions (including librarianship) are somehow a conspiracy against the public they purport to serve" (Usherwood, 1980, p.10). In Usherwood's view, an ethical code was an important part of re-engaging with the social goals of libraries, that:

"it is not anti-social or necessarily self seeking to believe in and value the contribution one's profession can make in helping create a better world ... This is not an elitist view but simply a recognition that these are groups of people who have special skills, skills that can be used to benefit society at large" (Usherwood, 1980, p.12).

Abbott makes some interesting suggestions about how we can accommodate these concerns about our status. While some held the view that "Professionalization was as inevitable as an escalator" (Abbott, 1998, p.431) Abbott sees "no sense in differentiating professions and semi-professions; they are all simply expert occupations finding work to do and doing it when they can" (p.433). In Abbott's view whether or not librarianship classed itself as a profession or a semi-profession, the common aspect of both is a set of professional values:

"Does the foundation (and consequently, the justification) of librarianship lie in its technological expertise, increasingly the justification used by most other professions? Or does that foundation lie in a commitment to access, a kind of democracy of culture?" (Abbott, 1998, p.439).

Abbott describes librarianship as "a federated profession," "a loose aggregation of groups doing relatively different kinds of work but sharing a common orientation" (p.441). Therefore we can delineate a profession that is keen to assert its role within society, but one that seems unsure or lacks confidence in that.

Gorman himself cites the Five Laws of Library Science espoused in 1931 by S.R. Ranganathan, as an inspiration, and no paper related to the values of librarianship could begin without summarising them. The five laws were:

- Books are for use.

- For every reader, his or her book.

- For every book, its reader.

- Save the time of the reader.

- A library is a growing organism (Ranganathan, 1931)

While the terminology is historically grounded the ethical backbone such principles provide remain relevant. Ranganathan has been interpreted exhaustively over the years since his five laws were first published, but a simple translation of them for the modern era would be that librarians must encourage all potential users to access information; regardless of creed or colour there is something a library has that will be of value to a user; that librarians ensure that the way they organise and store the material is for the benefit of the user and not their own; and that they continue to add to the collections they make available to people. At the heart of Ranganathan's laws are the universal notions of equity of access to, and availability of, information for all. 
Gorman's Enduring Values

Recently M ichael Gorman made an attempt to revisit the guiding principles and values of librarianship: he identified 8 themes that he calls enduring values. Michael Gorman's work could be argued to be the most ambitious attempt to define a core set of values for the library profession since S.R. Ranganathan's Five Laws of Library Science. Gorman reviews many other texts on librarianship and ethics, and find 8 common values which he defines as core values in librarianship. However, to Gorman these values are not absolutes, indeed the values are of more importance if each generation can change, adapt or reinterpret them. In addition the "values are, inescapably, in conflict and must constantly be weighed one against the other" (Gorman, 2000, p.5). The values are:
1. Stewardship
2. Service
3. Intellectual Freedom
4. Rationalism
5. Literacy \& Learning
6. Equity of Access to Recorded Knowledge \& Information
7. Privacy
8. Democracy (Gorman, 2000, p.26-27)

Stewardship has three elements, firstly preserving knowledge so that it is passed on to future generations, secondly in developing and carrying out librarianship training that passes on core values, and thirdly in building the trust of the communities served (Gorman, 2000, p.58-66). In the value of service there is a commitment to making all elements of a library user-friendly, in being courteous and approachable, and to measure all projects and plans in terms of service. There is also a strong resonance with Foskett's (1962) principles of favouring the disadvantaged, especially in public libraries where "the heaviest users [...] are the young and poorer senior citizens - the least powerful groups in our society."

For Gorman, it is important to define intellectual freedom as a value to actively protect as laws are changed over time to restrict free speech on various subjects. At this current time, sexual expression is the main culprit in terms of legislation; at other times blasphemy or political expression has been restricted. Gorman asserts that librarians "should hold fast to intellectual freedom and carry out tasks without reference to our own opinions or the opinions of those who want to restrict free access to knowledge" (Gorman, 2000, p.90). However, he recognises that censorship is an issues librarians are confronted with continually, especially, for example in small towns or school libraries where interest groups can exert influence. In these sorts of circumstances, Gorman would rather see small compromises made than a librarian leave their job on principle and allow someone with different values take their place. However, where possible he urges librarians to advocate greater intellectual freedom and to fight censorship where it occurs, especially when it is reactionary, for example in internet filtering, where a danger is perceived from a new technology that is not actually all bad, and where filtering is also ineffective.

In the value of rationalism Gorman also emphasises that this is not an absolute: "rationalism is an approach, not a prescription", but that libraries are "the children of the enlightenment and of rationalism, They stand, above all, for the notion that human beings are improved by the acquisition of knowledge and information and that no bar should be placed in their way" (Gorman, 2000, p103) and to this end, librarians should organise libraries rationally, using bibliographic control sensibly and adopting useful management structures and not unnecessary bureaucracies. They should also spread rationalism when instructing library users, and as they are more and more able to access catalogues and myriad electronic and other resources directly. Librarians should not only teach basic skills such as 
searching for and retrieving resources, but critical thinking and how to evaluate resources, to enable users to select the most appropriate sources.

Gorman's fifth value of Literacy and Learning states that there is a danger that society is dividing into three tiers, a 'reading elite', the 'alliterate'; people who can read but who depend on the television for most of their information, and the illiterate. For Gorman, literacy is about more than reading, it is about being able to 'express oneself fully' (Gorman, 2000, p.13) and about empowerment: the ability of anyone to improve themselves and the potential to become as knowledgeable as anyone else. Otherwise, commercial interests will dictate what information people access and this could be dangerous. In many of these values, there is a clear social element and this is also true of the value of Equity of Access which for Gorman is part of a concept of social justice, that "everyone deserves and should be given the recorded knowledge she wants no matter who she is" (Gorman, 2000, p133). Implementing this involves removing barriers to access and being sure not to favour the better-off or powerful. As many things can affect a person's ability to access information, this process must be continuous.

Gorman recognises that Privacy has been compromised by technology, often unintentionally. He sees this as regressive, that "cyberspace resembles nothing as much as a medieval village - a place in which privacy was unknown" (Gorman, 2000, p.145). In Gorman's view, if librarians are to prevent the erosion of the legal right to privacy, they must constantly be vigilant "to the possibilities for snooping and more sinister uses of data about personal use of electronic resources." Democracy is key, and underlies all the values of librarianship: "intellectual freedom, the common good, service to all, the transmission of the human record to future generations, free access to knowledge and information, non-discrimination [...] A librarians who is not a (small "d") democrat is almost unthinkable" (Gorman, 2000, p.160). For democracy to flourish in any country, these values are important for giving citizens access to the information they need to participate in democratic processes.

\section{Aims and Methodology}

This article has two main objectives:

1. To examine the ethical codes of information professionals from around the world to examine what the codes have in common, what marks them apart and to explore the ways that the political, historical, cultural contexts in which different codes have been produced has influenced their content.

2. To critically examine whether an international ethical code can be synthesised, by exploring the consequences of the variations found in the codes, looking at the content of the codes not only for areas of consensus but for areas of conflict and disagreement. This should test out whether indeed "the rest is commentary" as Koehler and Pemberton assert (2000, p39). By looking in detail at the values contained in the codes it should be possible to test out whether any differences in the codes are superficial, subtly influenced by the context in which they were written or more deeply affected by their context rather than by a set of values common to the profession.

There are commentators who criticise codes of ethics for being too 'imprecise' (Samek, 2001) or too general and lacking relevance to the situations facing professionals on a day-to-day basis (Rothstein cited in Gorman, 2000, p21). On the other hand there are those who criticise a "lack of philosophy" in librarianship (Foskett, 1962, p.4).

Koehler and Pemberton distinguish between "aspirational" and "mandatory" ethical codes (Koehler \& Pemberton, 2000, p.29). By using Gorman's values, there is the risk that the research for this paper 
will err to the side of the 'aspirational' codes, however, each of these values relates to real practical elements of information and library work. In the examination of the codes' treatment of these themes, the practical consequences of the differences are explored. In addition, any values which occur in any of the codes under study that contradict Gorman's 8 values will also be discussed.

Quantitative analysis

Another advantage of using a set of specific values to measure the codes against rather than synthesising a set of values based on the codes, is that these 8 values are independent and provide a yardstick to measure just how different the codes are. Each code will be examined to determine if it contains each of Gorman's values. This will be one way of establishing, at a glance, any major differences in terms of which values are expressed in the codes.

Qualitative analysis

The quantitative analysis will be built upon in an in-depth qualitative analysis of how each code expresses each of the 8 values. For each code, literature will be presented that will give the context of the codes, such as geographical, political or cultural factors. This is to ascertain how much of an influence these factors have, to test out how 'enduring' the values actually are, and to find out to what extent they are influenced by geographical, political or cultural situations. It might be found that in some situations these influences outweigh those values considered common to the whole profession; in others it may be the case that while the cultural or political situation has an influence, the differences between the codes are subtle.

\section{Limitations}

The paper will examine only the national level general professional association codes. This is for a number of reasons, not only convenience but due to practical limits. The majority of the national codes are available on the Internet through IFLA/FAIFE's project to collect these codes, and unless otherwise stated in the text, this site is the source for the text of each (IFLA, 2009). Any additional national codes are taken from Valdosta State University's page on ethics codes, which is cited as the basis of Koehler's 2006 article, as this is the most recent and comprehensive source on the number of national organisations which have ethical codes.

An additional reason for restricting the codes to the national level is that it would be difficult to gain access to the appropriate sub-national level literature. For each code, literature will be presented which puts the content of the codes in their geographical, political or cultural contexts. While it would be difficult to do this in detail from the UK for codes from outside the UK, there should be sufficient material available to build up a picture at a national level.

\section{Analysis of the codes}

Each of the 36 ethical codes was analysed for their similarity to Gorman's 8 values. Codes were characterised as adhering to a specific value, partially adhering to a value, or not adhering to a value. Chart 1 illustrates the breakdown of the number of codes that related to each of the values espoused by Gorman. 
REVIEWED AND AMENDED VERSION TO BE PUBLISHED IN JOURNAL OF LIBRARIANSHIP AND INFORM ATION SCIENCE IN M ARCH 2013, ISSUE 45 (1)

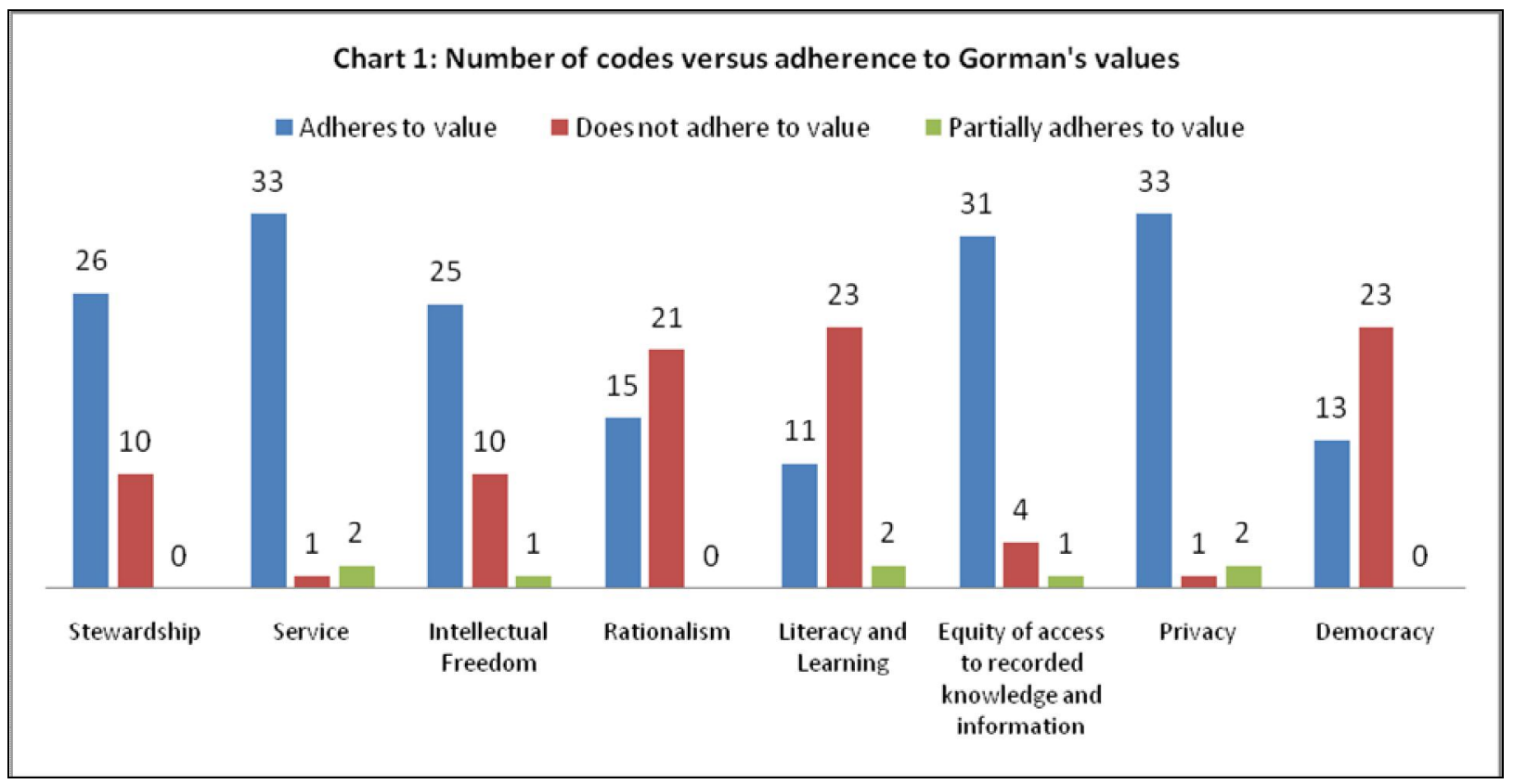

Figure 1 below illustrates the number of values adhered to by each code, by country.

\begin{tabular}{|l|l|l|l|}
\hline Country: & $\begin{array}{l}\text { Adheres to one } \\
\text { or more values }\end{array}$ & $\begin{array}{l}\text { Does not adhere to one } \\
\text { or more values }\end{array}$ & $\begin{array}{l}\text { Partially adheres to one or } \\
\text { more values }\end{array}$ \\
\hline Japan & 8 & 0 & 0 \\
\hline Netherlands & 7 & 1 & 0 \\
\hline France & 7 & 1 & 0 \\
\hline Czech Republic & 7 & 1 & 0 \\
\hline Botswana & 7 & 1 & 0 \\
\hline Hungary & 7 & 1 & 0 \\
\hline USA & 6 & 2 & 0 \\
\hline Italy & 6 & 1 & 1 \\
\hline Ukraine & 6 & 1 & 1 \\
\hline Lithuania & 6 & 2 & 0 \\
\hline Malaysia & 6 & 2 & 0 \\
\hline Poland & 6 & 2 & 0 \\
\hline Korea & 6 & 0 & 2 \\
\hline Croatia & 6 & 1 & 1 \\
\hline Israel & 6 & 2 & 0 \\
\hline Germany & 6 & 2 & 0 \\
\hline Armenia & 5 & 3 & 0 \\
\hline Sweden & 5 & 3 & 0 \\
\hline Australia & 5 & 3 & 0 \\
\hline Hong Kong & 5 & 3 & 0 \\
\hline Canada & 5 & 3 & 0 \\
\hline Slovenia & 5 & 3 & 0 \\
\hline Estonia & 5 & 3 & 0 \\
\hline Switzerland & 5 & 3 & 0 \\
\hline Portugal & 5 & 3 & 0 \\
\hline Jamaica & 4 & 4 & 0 \\
\hline & & \\
\hline
\end{tabular}


REVIEWED AND AMENDED VERSION TO BE PUBLISHED IN JOURNAL OF LIBRARIANSHIP AND INFORM ATION SCIENCE IN M ARCH 2013, ISSUE 45 (1)

\begin{tabular}{|l|l|l|l|}
\hline M exico & 4 & 4 & 0 \\
\hline $\begin{array}{l}\text { Russian } \\
\text { Federation }\end{array}$ & 4 & 4 & 0 \\
\hline New Zealand & 4 & 4 & 4 \\
\hline Philippines & 4 & 3 & 1 \\
\hline United Kingdom & 4 & 4 & 0 \\
\hline $\begin{array}{l}\text { Australian } \\
\text { Aboriginal }\end{array}$ & 4 & 4 & 0 \\
\hline Sri Lanka & 3 & 4 & 1 \\
\hline Native American & 3 & 5 & 0 \\
\hline Indonesia & 2 & 5 & 1 \\
\hline Singapore & 2 & 6 & 0 \\
\hline
\end{tabular}

In the following section each of Gorman's values and the adherence of codes to them will be discussed separately.

\section{Stewardship}

Within the theme of stewardship, the codes deal with this in a variety of ways while assigning stewardship different levels of importance:

Preserving Cultural Heritage for future generations: a few of the codes underline what they see as the essential role of libraries in preserving human knowledge for future generations. For some, this is one of the most important responsibilities of libraries. The Korean code takes the long-term view that "the transmission of the memories of nations and the humankind, have heavy responsibilities," similarly German librarians are obliged to "preserve heritage holdings for future generations", and in New Zealand the "collection, preservation and availability of recorded and transmitted knowledge and ideas" are high priorities.

Towards the lower end of this scale, the UK code recognises the cultural value of information without putting so much emphasis on the grand scale of human history. The code expresses "Concern for the conservation and preservation of our information heritage in all formats." The French code also sees the librarian's role as to "build[...] up the public collections, and makes sure of their civic use and display."

Although these codes do see stewardship of cultural items as for the good of society, they are more specific, requiring librarians to build collections appropriate to the community they serve. M any codes do not make direct use of the terms 'stewardship' or 'preservation', however there are more subtle expressions of this value. The Canadian code makes a straightforward statement that we "shall acquire and make available the widest variety of materials".

A number of codes make no mention of stewardship or preservation issues, for example the Hong Kong code only urges librarians to "provide well-organized collections", which would refer more to the organisation of collections than to their actual development, and the Sri Lankan code makes no discernible mention of stewardship at all, instead focusing mainly on dealing with serious misconduct and bringing the profession into disrepute.

Nationalistic preservation issues

Some of the codes have a nationalistic attitude towards stewardship. Some mention both the need to preserve world heritage and specifically national cultural material, e.g. The Hungarian code says: "preserving the cultural heritage of mankind, including that of Hungary, national and ethnic minorities, 
as well as local communities." The Armenian code asks all librarians to preserve both "the intellectual values of Armenians and of all nations, assists in their enrichment, and supports the cultural development of the national minorities living in Armenia." Armenia has been through invasion, war and dictatorship. Particularly the Armenian experience of war, and the country's desire to have the deaths of thousands of Armenians in the 1915-1917 war with the Ottoman Empire recognised as a genocide could be one of the reasons why preserving material from national minorities is important in this code. Another code which has a nationalistic attitude is the Ukranian code, according to which librarians "preserve and replenish spiritual values of [the] Ukrainian nation, [and] promote the development of ethnic cultures." Again this is another country which has had experience of cultural upheaval, having achieved independence less than 20 years ago.

\section{Stewardship of culturally sensitive material}

The majority of codes which emphasise stewardship also relate this to making material available. By contrast, the Native American code expresses a different set of values entirely. The code emphasises "shared stewardship", and the need to balance the needs of native tribes and the nation as a whole. The code contrasts the 'western' conception of property with the Native American conception, whereby a tribe belongs to the land or intangible things such as traditions, rather than those things belonging to the tribe. This creates conflict, particularly in the area of intellectual property. For Native Americans, a book which contains information on tribal traditions or a video of a tribal cultural event has stronger ties to that community than to that author: "one problem with copyright from an Indigenous perspective is that it expires and protects authors and publishers but not the interests of those whose culture is described or depicted" (Native American code). Western institutions also have difficulty with recognising community ownership over intangible cultural material. This can be difficult for libraries and archives to deal with, and the code recommends building links with communities to share decision making over culturally sensitive material held in library and archival collections. Solutions include moving items closer to the relevant community so that the items do not "become estranged", repatriating items especially if they have been acquired by deception or subterfuge, even if this means that items are not preserved, and "at the request of a Native American community, avoid artificially prolonging the life cycle of sensitive documentary material." Although this means allowing some items to disintegrate, there are also positive actions which can be taken, such as making a concerted effort to collect items by "created by rather than just about Native Americans."

The Native American stance is supported by a draft UN Declaration on the Rights of Indigenous Populations, supporting community ownership of 'cultural patrimony'. However, there is no evidence in the ALA code of ethics which recognises this area in terms of stewardship. The ALA code simply makes reference to preservation and states that "We have a special obligation to ensure the free flow of information and ideas to present and future generations," which neglects to mention the complexities of this area of work in one of the countries most affected by this issue.

\section{Service}

Service is one of the most commonly expressed values, featuring in 32 of the codes. Of those codes which did not contain this value, the Native American Code is quite specific to two or three issues and does not deal with every aspect of information and library work. The Ukrainian and Croatian codes make no specific mention of service, however there is nothing which suggests opposing this value, in fact it could be argued that the spirit of service is expressed in these codes, for example by phrases such as "we respect human dignity," from the Ukrainian code and "professional responsibility to the public," from the Croatian code. Although service is a common and seemingly uncontroversial value, there are degrees of variation in how this value is expressed. Some codes describe service in fairly grand terms, for example "Librarians serve people with devotional attitude," from the Korean code, others describe service as a "primary duty to their clients and to society," from the New Zealand code. 
The UK code seems quite reluctant to commit librarians to service, describing them as simply: "services which the members are engaged to provide" (CILIP, 2007).

$M$ any codes focus on the need to be unbiased and non-discriminatory in providing information and library services to individuals, but the Indonesian code describes "service to the society" and the need to "upgrade the knowledge and prosperity of society, nation and country." The impression from the Indonesian code is that librarians are primarily servants of the state and society. The Philippines code is similar in putting the "well-being of the public and interest of the State [...] above the wellbeing and interest of any individual." Other codes require librarians to be loyal to their employers, for example the Hungarian code asks that librarians be "loyal to their library."

Balancing different responsibilities, to the individual, the library or employer, society and the state, are at the centre of our ethical decision-making according to M CM enemy et al $(2007$, p.12. ). This suggests that while the ethics codes can set out some general principles, these principles can still come into conflict at times.

\section{Intellectual Freedom}

Intellectual freedom is both about freedom of expression and opposing censorship. Many of the codes which omit any mention of censorship are democratic countries where perhaps librarians do not feel censorship is a threat, such as the UK, Sweden and Switzerland. A significant majority (6) only refer to opposing censorship, and do not mention intellectual freedom. Three other codes, the Russian, Armenian and Slovenian codes, only refer to librarians taking no responsibility for what is done with information given out, which could be interpreted as some sort of intellectual freedom. A number of codes put limits on intellectual freedom, making specific restrictions on material made available. One of the most concerning is the Czech code which advocates no "censorship, save for the exceptions stipulated by legislation", which leaves the question of what kind of censorship may be required by law? This could relate to state secrets, although it would seem to be more the prerogative of the government to impose this rather than librarians who are hardly national security experts.

Other codes require librarians to protect children from certain material, e.g. "We protect children and youths from contents unsuitable for them according to the Young Persons Protection Act and other legal regulations," from the German code. The Israeli code opposes censorship but justifies selection of materials that "is relevant to the goals of the library and meets its standards."

\section{Rationalism}

For Gorman rationalism is about the use of reason as opposed to being guided primarily by religion, emotion, faith or spirituality. Within a library context this means organising resources to enable access and organising the institution of the library, having reasonable staffing structures and so on. The term itself only appears in one code, and is one of the least popular values as it appears in only just under half of the codes. The main way in which is expressed is through an obligation to organise resources in the library collection. For example, this is the statement from the Estonian code: "We provide open access to the global information with our well-organized book collections." Rationalism is also about separating personal and professional beliefs. Many codes make reference to this; however some question whether this is ever really possible. Irish argues that librarians cannot be expected to behave like "robots", following a set of rules to the letter, and that when someone believes in a "higher ethical standard", such as a religious faith, this can override professional standards in extreme circumstances (Smith (Ed), 2002, p120-129). 
The only code which makes explicit reference to rationalism is the Polish code which sees librarians as "referring to the rationality, common sense and the best professional practice" and the code goes into some depth about being guided by user need when organising resources, organising them sensibly and without discrimination. This helps make it clear why organising resources is an ethical matter as well as a practical one. By contrast, a large number of codes make reference to making resources available, but make no reference to organising resources. This could be because it is such an everyday aspect of library work, and yet the ethical issues perhaps occur so infrequently that it is not viewed as an ethical issue. However, if no recognition is made of the ethical dimension of organising resources, the problems such as the continuation of discriminatory or derogatory terminology in classification and the use of redundant terminology which does not help patrons use the library, which are referred to in the Polish code, might well continue.

A number of codes do make reference to the importance of religious or spiritual values in librarianship. For example, the Native American code acknowledges holding principles which are different to many traditional librarianship values, and seeks to explain a different "knowledge system":

"It's a whole system of a way of life. Our knowledge systems don't make sense without spirituality. We are asking for respect for a system of knowledge -Kim Lawson (Heiltsuk Nation)."

The Indonesian code begins with "God's blessing," and requires librarians to "love Indonesian identity and culture". M cM enemy et al question whether "in a single-faith state, is such a call problematic?" (2007, p37). However, although Islam is the dominant religion in Indonesia it is not the state religion and many other faiths are represented in Indonesia. The Indonesian state recognises some other religions, and in theory citizens have religious freedom, however there have been religious tensions and religious killings in Indonesia (Bureau of Democracy, Human Rights, and Labor, 2004). Therefore the inclusion of a religious sentiment in the ethical code is not exactly neutral, although it is not clear (at least in the English version) if the code is specific to Islam.

In terms of rationalism in the organisation of the staff and institution of the library, the Polish code is again clear on this that the library should be "free of artificial hierarchy, authority and ritual." A number of codes make statements about needing to be unbiased and professional, which could be seen as a type of rationalism, although it also relates to preventing corruption and building public trust. Some of the codes use bureaucratic language, which could be a sign of a lack of rationalism in the codes themselves - for example the Hungarian code spends over 150 words simply explaining the "pyramid structure" of the code itself.

\section{Literacy \& Learning}

According to Gorman literacy is about more than the ability to read, it is also about having critical faculties and an ability to engage critically with information and not to simply accept statements as fact but to take into account factors such as reliability of sources. Many of the codes simply refer to making resources available and make no mention of libraries as places which actively teach; rather the fact of making information available is seen as making learning possible. For example the Korean code which "promote[s] the people's willingness to self-growth" or to "raise public awareness" of ILS services, form the Portuguese code. However, awareness is not quite the same as understanding and Gorman is clear that he sees this role as being more active. This was one of the least popular values, with only around a third of the codes making reference to an educational role for libraries. It was also scarcely mentioned in the literature available around ethics in librarianship, although some see teaching literacy as potentially our most powerful skill (Samek, 2001, pxii). 
Those codes which do refer to an educational role for libraries or librarians hardly give it a prominent role. Many of the codes which do make reference to education emphasise self-education of awareness-raising, for example the French code in which librarians "guarantee the users' autonomy, make them respect the documents, and promote self-education", which only implies some sort of training although it does not make it clear how librarians will guarantee patron autonomy.

Similarly Israeli librarians, "encourage potential users of the library under his/her care to be aware of the existence of the library and how to use its services," which again puts any teaching role as secondary to awareness-raising. The Polish code is perhaps nearer to Gorman's conception of literacy as empowering people to take part in society, as in this code librarians "actively disseminate in the community the awareness of the importance of knowledge and information." Others see libraries as having a general cultural and educational purpose, such as the Botswana code: which sees libraries as "stimulating the development of cultural environment" (BLA, 2001) and the Czech code which describes libraries as "being an important cultural and educational centre of the town."

Only two codes refer to promoting reading, which seems extraordinary. Even then, the Japanese code again puts libraries in a secondary role in this, supporting other groups which promote reading: "Librarians need to have a deep understanding for any voluntary movements among local residents for developing reading habits and promoting private library services for children." The Netherlands is clearer that libraries are to "promote reading and the use of information." Explicitly describing librarians as carrying out teaching is equally unpopular, with only the Indonesian and Croatian codes using these terms: "librarians is a profession, which mainly carries out educational tasks and research," from the Indonesian code and "professional involvement in teaching," from the Croatian code.

This reluctance to use terms such as teaching or education could be due to teaching being seen as another distinct profession with its own training systems. However, many of the codes which do not mention literacy or learning do make it clear that libraries have a social role, especially not to discriminate against the socially disadvantaged. It seems that one of the biggest obstacles which would hinder library users would be a lack of literacy, and simply making items available for use would not overcome this barrier to access.

\section{Equity of access to recorded knowledge $\&$ information}

Equity of access to recorded knowledge and information is a broad topic, covering both what is made available to the public and issues of non-discrimination in providing that information to the public.

\section{Non-discrimination against users}

The vast majority of the codes make some assurance about non-discrimination in providing service to users. The exact formulation of this varies, some codes make a general assurance such as "respecting the diversity of the users," from the Polish code or "Libraries should be discrimination free zones," from the Botswana code (BLA, 2001). Others list specific areas of discrimination to be avoided - again there are variations here, some are extensive such as the Armenian code, which says "The relations of a librarian and a user are founded on mutual respect, without regard to their nationality, race, social status, political opinions, religion, gender, and age differences".

It is likely that statements on non-discrimination will change over time, as discrimination may be unintentional or go unnoticed for a long time. Different issues and areas of discrimination may come under scrutiny over time, for example none of the codes made reference to HIV status, which could be put down to changing attitudes about the disease, and perhaps many library associations would add this now if they rewrote their codes, rather than this omission showing any intention to discriminate on these grounds. The Netherlands code takes a different approach, instead of not discriminating 
against people, in the Netherlands "The librarian [...] contributes to the processes of emancipation of certain groups in society," which is both more active, more positive and puts librarians in the shoes of the minority or discriminated-against groups, whereas all the other formulations assume that the librarian will be in the position of a powerful elite which has the power to discriminate or not against certain people. Samek certainly sees librarians in an active role: "as active participants and interventionists in social conflicts" (Samek, 2001, p.7). One startling omission from almost all of the codes is the need to provide equity of access for disabled people. In some countries librarians are coming face-to-face with libraries lack of provision for a whole range of disabilities; in the UK for example The Disability Discrimination Act 1995 makes it unlawful to discriminate against people with disabilities, and requires service providers to make adjustments to accommodate all users, although there are some exceptions. A more proactive attitude such as the one expressed in the Netherlands code might help librarians to see their blind-spots such as this when it comes to discrimination.

\section{Discrimination in information Selection/provision}

A surprisingly small number of codes make it clear that there is a difference between selection and censorship. The US code does acknowledge that the influence librarians have in selection is "significant," as does the Malaysian code. Most of the codes make some statement about librarians not showing any bias in the provision of information; the Swedish code for example states: "The librarian shall treat library users with respect and good judgement: impartially and equally." Many of the codes require librarians to distinguish between their own opinions and their professional decisions. The American code is typical: "We distinguish between our personal convictions and professional duties and do not allow our personal beliefs to interfere with fair representation of the aims of our institutions or the provision of access to their information resources."

Several of the codes put specific restrictions on what recorded knowledge is available to users. For example, the UK librarians are not to "knowingly promote material the prime purpose of which is to encourage discrimination on the grounds of race, colour, creed, gender or sexual orientation" (CILIP, 2007). The Israeli code directly contradicts this, saying: "The librarian does not disqualify material for being controversial or possibly offending some library users." Other codes make reference to specific restrictions in law. The German code refers to a law which effectively restricts the material made available to young people and teenagers, although this is described as "protect[ing] children and youths from contents unsuitable for them." This code seems to contradict itself, as it also states that "We reject censorship of content."

The Native Peoples codes provide interesting contrasts with the other codes. The Aboriginal code explains how in some circumstances, the way in which information is provided can discriminate against users; for example if offensive terminology is used this will discourage aborigines from using their local library as "No person is likely to willingly go to a place which portrays or displays them in a way that is alien and degrading." The code urges libraries to take measures against these consequences, such as positive discrimination to recruit more aboriginal staff, developing closer links with aboriginal communities and liaising over treatment of offensive material. The Native American code advocates adding "explanations of derogatory words to original titles (e.g., [title created by xxxx in xxxx year]) or remov[ing] offensive terms from original titles and provide substitute language (e.g., replace "squaw" or "buck" with [woman] or [man])." In addition both the Aboriginal and Native American codes make a number of interesting points which contrast strongly with the majority view that allowing access to the full range of recorded knowledge is good for society. For example, there are both 'sacred' and 'secret' items which have been collected by archives over the years which may have been obtained by deception. The Native American code further explains that some information may even be considered "a matter of "national security" for sovereign tribal governments." Taking into consideration these 
concerns, both of these codes make it clear that there are types of information to which access should be restricted.

\section{Privacy}

M ost of the codes mention user privacy in some way, however within this there is a broad spectrum. $M$ any of the codes require librarians to respect user privacy within the bounds of the law, for example the German code states that:

“We respect our clients' privacy. Personal data will be saved only to ensure service delivery and only within the legal framework. We will share personal data with other institutions only as required by law."

The British (CILIP, 2007), Japanese and Netherlands codes all put limitations on privacy within the laws of those countries. Many of the codes make no mention of legal restrictions such as the Israeli, Australian and Malaysian codes. By contrast, some countries' codes actually guarantee the privacy of user data - such as the Italian code according to which "The librarian guarantees the confidentiality of the user, of the information he requested or received and of the information sources used."

This type of assurance may be of concern in a number of ways. When this assurance is unrealistic such as when the ALA code assures us that "protect each library user's right to privacy and confidentiality with respect to information sought or received and resources consulted, borrowed, acquired or transmitted," however it is well known that since the introduction of the PATRIOT Act the protection librarians can offer is limited by law. Although the ALA did take an active stance in opposing some parts of the PATRIOT Act (Pike, 2006) the Act means that law enforcement agencies can require records without the knowledge of the individual concerned. The balance of control over patron privacy may have tipped towards the law enforcement agencies, and so these assurances may be misleading.

\section{Privacy and electronic data}

The Italian code is typical in assuring users that confidentiality extends to both items borrowed but also to information sought or received. Very few of the codes make mention of the privacy of electronic data which is significant as in traditional library work, such as face-to-face reference enquiries, leaves no or little written record, and in this context protecting privacy would be a case of exercising discretion, for example the Singapore code mentions librarians being discreet in dealing with enquiries. However protecting privacy in an electronic context may be difficult - guaranteeing it may be all but impossible. In fact in Italy, there are moves to require Internet Service Providers to collect traffic data, which would include libraries (Monti, 2004).

If a library user makes an enquiry at a library helpdesk they can usually be assured of privacy, however if they seek out an answer to the same enquiry on a computer in that library and use the search engine Google, Google can keep that data and there is little the library can do about that. If one of the purposes of the codes is to inform users as to what they can expect from librarians, the codes could at least include an obligation for libraries to keep users informed as to what limits on their privacy exist simply by the provision of computers and internet services. Alternatively, although in many areas where ethics statements deal with principals those principals can be applied to new technologies and situations, it may be helpful if more codes made it clear if librarians are expected to actively delete computer records such as weblogs.

Among the few codes which makes any reference to specific issues in an electronic environment is the Polish code which makes a general recommendation that librarians "comply with the regulations on the use of computer hardware and software, including license agreements, and the netiquette," but 
this is only the equivalent of requiring librarians to have "kind and friendly manners" as the Korean code does, or to be "courteous" as the Malaysian code requires, when something more substantial is needed. The Portuguese code states that "records kept on paper or in computerised form are not left in places where they can be easily accessed or read by other users." Implicit in this is that these records may be accessed by people who are not library users, but surely library patrons are entitled to clearer information than this. Librarians and users could benefit from clearer guidance on this.

\section{Democracy}

Former Soviet Block

As democracy is more than an ideal, it is a political model which Gorman recognises is often "imperfectly achieved" (Gorman, 2000, p.160), this is an area where ethical codes might be expected to diverge. Many librarians work in non-democratic countries, where access to information may be restricted and being seen to promote democracy in a direct or indirect way may put librarians in danger. McMenemy also points out that this value is controversial, as it could put librarians in the position of "espousing western values" (M cM enemy et al, 2007, p.16).

On the other hand many librarians who do live and work in democratic countries may be surprised that Gorman placed so much emphasis on democracy, perhaps taking democracy for granted and not seeing libraries as particularly concerned with politics. Democracy is not mentioned in many of the ethical codes, however among those which do are a number of countries which have gained their independence since the collapse of the Soviet Union in 1991, including the Ukraine, the Czech Republic and Hungary. The Ukrainian code describes libraries taking an active role in developing and promoting democracy, "building up democratic and independent Ukraine," whereas the Czech code uses democracy as a value which should be a quality of libraries themselves, describing libraries as "public, democratic institutions." The Hungarian code states that "Librarians respect and are committed to human rights, democracy, the legal state, equal social opportunities, intellectual freedom and the freedom of information". This contrasts with the UK and US codes which perhaps surprisingly omit any mention of democracy. It seems that countries with a recent experience of a dictatorship are more likely to explicitly raise the issue. However, the UK and US codes do deal with equal access to recorded knowledge and information.

\section{Hong Kong \& Russia}

The term 'democracy' is also conspicuously absent from the Russian code and the Hong Kong Code. At the time of the fall of the Soviet regime, some libraries suffered as funding from the state dropped. Libraries were competing with hospitals and other essential services for money and often lost out (Kuzim, 1993, p.569). This was at a time when demand for libraries increased as books became more expensive and the centralized government book distribution system disappeared. As has been observed, democracy and free access to information are interlinked. For example Pateman (1998) argues that the Communist regime across Eastern Europe increased the number of libraries and improved literacy. However, quantity does not mean quality - as Kuzim puts it, with reference to the Soviet Union, "The old regime knew what it needed libraries for: to support that regime with Communist propaganda" (1993, p.570).

The Hong Kong code was agreed by the Hong Kong Library Association two years prior to reunification with the Peoples Republic of China, and this raises questions about how librarians should deal with the potential for political change in any country. This code was introduced at a time of uncertainty and anxiety, when some librarians were fleeing to Europe and North America: 12 out of 73 public sector librarians had left by 1993 (Storey, 1993, p.30). Although the Hong Kong code does not mention democracy specifically, it does state that librarians should oppose censorship and promote intellectual freedom. In a true democracy all citizens have access to the information they need to make their 
participation in democratic processes informed and therefore meaningful. Although Gorman sees the fate of libraries as linked to the success of democracy, as libraries "have grown and flourished in the soil of democracy" (Gorman, 2000, p160), totalitarian regimes or dictatorships are interested in controlling information rather than libraries themselves. So committing librarians to "freedom of enquiry, thought and expression and in the free, uncensored flow of information," as the Hong Kong code does, is highly political and opposes libraries being used as tools of a repressive regime.

Loyalty \& professional independence

Of all the codes, only the Slovenian code makes specific mention of librarians needing to be aware that their values are independent of the political situation they are in, describing the purpose of the code as to "form the personality of a librarian independently of the current political situation." M cMenemy et al describe the dangers of librarians becoming too close to any one government, as government priorities change over time (McM enemy et al, 2007, p.23). Many of the other codes leave librarians vulnerable to all types of political change. For example, while some codes make reference to specific laws which librarians should follow, some make very generic statements such as "[the librarian is] conscious of his responsibilities and anxious to enforce the current laws and rules," as the French code does, or to abide by "current legislation, as in the Mexican code. The danger of these statements is that laws change and the ethical codes will not necessarily keep up with the law.

By contrast the Portuguese code lists one of the responsibilities of librarians as "To draw up, participate in the preparation of, know about, support and publicise all legislation relating to the right of access to information without any interference whatsoever." Some codes strongly require librarians to be loyal to the State - the code of the Philippines puts the interest of the State above the interests of any individual and requires librarians to be loyal to the State: Librarians should recognize and respect the supreme authority of the State as expressed through its laws and implemented by its agencies. Librarians should always observe that the well-being of the public and interest of the State are above the well-being and interest of any individual.

Similarly, the Singapore code states that: "The librarian must give complete loyalty and fidelity to the policies set by the governing authority" without making clear what these policies. The consequence of this is that librarians may be required by their professional associations to enforce policies that are anti-democratic; they could be required to censor information. In fact by putting State policy or law above professional and independent values they are in fact stating values which are directly the opposite of other ethical codes.

\section{Conclusions}

The objective of this paper has been to examine the content of ethical codes from around the world to test whether librarians share values, and to gauge to what extent geographical, political and cultural differences affect the values expressed in the ethical codes. The analysis took for form of some quantitative analysis and an in-depth qualitative analysis of the ethical codes.

In the quantitative analysis of 36 codes found a majority agreeing with 5 out of Gorman's 8 values. Those values were:

- Service

- Privacy

- Equity of Access to Recorded knowledge and Information

- Stewardship

- Intellectual Freedom 
Furthermore, there was a significant minority of codes which did not contain the values of either Stewardship or Intellectual Freedom. The 3 values which did not appear in the majority of the codes were:

- Rationalism

- Democracy

- Literacy and Learning

On the face of it there are just 3 values on which there is a clear global consensus, and those values are Service, Privacy and Equity of access. Although Stewardship and Intellectual freedom also appear in the majority of codes, substantial minorities did not include these values. It seems that Rationalism, Democracy and Literacy and Learning are not part of librarianship's global values, although they do feature in a number of codes.

Overall, the ethical codes of library associations from around the world share a small core of values but outside of this small core vary widely in terms of the values they contain. This is apparent at a quantitative level, before looking in depth at how these 8 values are expressed.

The qualitative analysis goes beyond which values are contained in the codes and looks at how these values are expressed, and the variations in this.

Values which varied regardless of geographical or political factors

Although expression of the values varied, it does not always vary in line with geographical or cultural differences. Literacy $\&$ Learning was unpopular across all of the codes. The codes which did contain this value did not go into much detail, perhaps only referring to the educational role of libraries. By contrast, some codes referred to self-education and the making-available of resources. It seems that across the board, librarians do not regard it as their role to be educators. A common area of variation was whether codes made reference to the law or not. This type of variation crossed geographical boundaries. For example, privacy was one of the most universal values of the codes, and countries from Europe, South Asia and Australasia limited privacy by law, while some countries from the same areas did not put limits on privacy. In the area of privacy only 2 codes differed substantially: the Indonesian code which focused on protecting the privacy or secrecy of the state, and the Sri Lankan code which made a similar statement.

One of the least popular values was Rationalism. The countries which did express rationalism, usually in reference to organisation of resources, were geographically and culturally diverse. The omission of this value does have ethical consequences, as particularly explored in the Aboriginal and Torres Strait Islander peoples' code. The Aboriginal and Torres Strait Islander peoples have witnessed irrational and offensive terms being used in organising library resources. The Polish code was the only other code to fully explore the ethical dimension of organising resources. Rationalism in organising resources is a core element of information and library sciences. Librarianship scarcely makes sense without rationalism, as resources cannot truly be made available if they are not organised. The Aboriginal and Torres Strait Islander peoples' code also describes how use of offensive terms in cataloguing puts off users from the Aboriginal and Torres Strait Islander communities, which has an impact on how well libraries offer equity of access. However it does not seem to be considered an ethical matter by most of the library associations.

Values slightly influenced by geographical, political or cultural factors 
In the expression of Equity of Access to Recorded Knowledge \& Information, codes referred to different groups against which librarians and information professionals should not discriminate. This could show differences in attitude across the world, for example if a particular group is not included in a code, this could indicate that a group is discriminated against in a particular country. There is variation even where a value appears in almost all of the codes. Even in the expression of Service, there are significant variations in the tone of how this is expressed, from those which rate Service very highly and describe librarianship in almost devotional terms, to those which are very matter-of-fact. A small group of codes expected librarians to be loyal, either to their employer or to the state, which could bring priorities into conflict. Two the Asia-pacific countries, the Philippines and Indonesian codes particularly emphasised loyalty to the state and did seem to have a different conception of the main obligation of librarians to many of the other codes.

Values strongly affected by geographical, political or cultural factors Historical and geographical factors had a greater influence in the treatment of some values.

Considering that Gorman views Stewardship as the value which makes library and information work unique, there was a sizeable minority which did not include this value. Most of the codes expressed this value in a simple way, in terms of building up collections. But those codes which took either a nationalistic approach or made reference to stewardship in grand terms tended to be countries which have experienced war, colonial rule, conflict, invasion or occupation in the last century.

The value of Democracy was not popular in the codes of ethics and was similarly affected by the history of the countries concerned. All of the countries which did express democracy have all experienced non-democratic regimes, war, occupation, colonial rule or have gained independence in the last century, including five out of the seven former Soviet-run states represented. It also featured in the only African country represented here, Botswana, which was a British Colony until 1966. Germany, Switzerland, Japan and Korea have also experienced war, occupation and conflict during the Second World War at different points over the last century.

Australia only fully separated its parliament and laws form the British parliament and laws in 1986 (Country Profile: Australia, 2007). Countries which have not had recent experience of dictatorship or occupation were less likely to mention democracy, for example neither the UK nor US codes featured this value. Non-democratic countries were unsurprisingly underrepresented in the codes available; however democracy was not mentioned in the Russian code. It was also not mentioned in the Hong Kong code, which was written prior to reunification with China. Although not exactly democratic before reunification, the situation in Hong Kong is a reminder that regime changes can happen either suddenly or more subtly.

The recurring areas of variation are:

- Omission of some values where a code has been constructed for a specific purpose, such as the Aboriginal and Torres Strait Islander peoples code and the Native American code which deal mainly with specific issues to do with sensitive archive materials, and do not encompass all areas of Information and Library Services.

- Which principles the codes contain. Only one code contained all 8 values, while a third of the codes contained half of the values or fewer. The patterns of variation in the inclusion or not of Democracy shows particularly how the political situation of a country impacts on these ethical codes and the role which librarians see themselves in society.

- Whether a code limits some principles by the law or not, which principles it limits in this way, and how specific these limits are. 
- The relationship between professionals and the state, whether they are primarily servants of the state or independent professionals. Countries in the Asia-Pacific put more emphasis on the power of the state

- Countries which have experienced war, conflict, occupation or colonialism put more emphasis on stewardship and democracy than other codes.

\section{Conclusion and suggestions for future research}

The findings of this paper suggest that there is some degree of broad consensus around a small core of values, but that these values are not exactly the same as Gorman's 8 values. At least one of these values (literacy and learning) was largely absent from the codes, no matter which country or continent the code came from.

However, variations in the codes were sometimes startling. Gorman never intended these values to be seen as absolutes and indeed they were meant to be flexible according to the values and needs of different societies (Gorman, 2000, p.5). However, when a value can be interpreted so differently that codes can be seen to be expressing conflicting values, this raises serious questions about whether librarians share values at all. Even the core of values is very open to interpretation and a number of significant areas of variation have been identified. A value such as privacy can be interpreted so differently (the privacy of the individual as opposed to the privacy of the state, privacy limited by law or unlimited privacy) that it could be argued the interpretations conflict.

Further research could be directed towards creating a more detailed quantitative system for mapping variations in the codes. This would create a clearer picture of how the codes might fall into certain groups according to how they express each value, or if there is a dominant interpretation of each value. Although this paper explored values in the codes which conflict with Gorman's 8 values, there are other values in the codes. While Koehler \& Pemberton (2000) created 6 values based on the codes, more research is needed to explore all of the values in the codes and to record the major variations in those values. The value which did vary the most widely was the most political value of democracy. The relationship between the profession and the state was a topic which raised questions about how independent librarians and information professionals are in their ethical decisions.

Both of these issues point towards further research into the political dimension of librarianship: to what extent is the value of democracy integral to librarianship, how does an absence of this value effect provision of information and library services? What should the relationship be between librarians and the state, and what are the implications of this for the status of the profession?

\section{References}

Abbott, A. (1998). Professionalism and the Future of Librarianship. Library Trends. 46(3). pp.430-443

Botswana Library Association (BLA). (2001). Professional Ethics. Available from: http://www.bla.0catch.com/Ethics.htm Last accessed 9th September 2009.

Brint, S. (1994) In an Age of Experts: The Changing Role of Professionals in Politics and Public Life. Princeton: Princeton University Press.

Bureau of Democracy, Human Rights, and Labor. (2004). International Religious Freedom Report 2004. U.S. Washington: Department of State. Available from: http:// www.state.gov/g/drl/rls/irf/2004/35399.htm Last accessed 26th August 2009. 
REVIEWED AND AMENDED VERSION TO BE PUBLISHED IN JOURNAL OF LIBRARIANSHIP AND INFORM ATION SCIENCE IN M ARCH 2013, ISSUE 45 (1)

CILIP. (2007). Code of Professional Conduct. CILIP: the Chartered Institute of Library and Information, UK. Available from: http:// www.cilip.org.uk/professionalguidance/ ethics. Last accessed 9th September 2009.

Country Profile: Armenia. (2009). BBC. Available from:

http://news.bbc.co.uk/1/hi/world/europe/ country_profiles/1108052.stm. Last accessed 18th August 2009.

Country Profile: Australia. (2009). BBC. Available from: http://news.bbc.co.uk/1/hi/world/asiapacific/ country_profiles/1255673.stm. Last accessed 8th September 2009.

Foskett, D.J. (1962). The Creed of a Librarian - no politics, no religion, no morals. Library Association.

Gorman, M. (2000). Our Enduring Values: Librarianship in the 21st Century. Chicago: ALA

Editions.

Hauptman, R. (1988). Ethical Challenges in Librarianship. Phoenix: The Oryx Press.

IFLA (2009) Professional Codes of Ethics for Librarians .Available from:

http://www.ifla.org/en/faife/professional-codes-of-ethics-for-librarians Last accessed 8th September 2009.

Koehler, W .C. \& Pemberton, J.M. (2000). A Search for core values: towards a M odel Code of Ethics for Information Professionals. Journal of Information Ethics. 9(1). pp.26-54

Koehler, W. (2006). National library associations as reflected in their codes of ethics Four codes examined. Library Management. 27 (1/2). pp. 83-100. Available from:

http:// www.emeraldinsight.com/10.1108/01435120610647974. Last accessed 8th September 2009.

Kuzim, E. (1993). From totalitarianism to democracy: Russian libraries in transition. American Libraries. 24(6). pp.568-570

Lindsey, J.A. and Prentice, A.E. (1985) Professional Ethics in Librarianship. Phoenix, Oryx Press.

M cMenemy, D., Poulter, A., Burton, P. (2007). A Handbook of Ethical Practice: A practical guide to dealing with ethical issues in information and library work. Oxford: Chandos Publishing.

M onti, A. (2004). The legal duty of IAPs to preserve traffic data: a dream or a nightmare? International Review of Law, Computers \& Technology. 18(2) pp. 221 - 230 Available from:

http:// www.informaworld.com/10.1080/1360086042000223517. Last accessed 8th September 2009.

Pateman, J. (1998). Libraries in Eastern Europe: then, but not now. Focus on International and Comparative Librarianship. 29 (2). pp.110-15

Pike, G. H. (2006). USA PATRIOT Act: What's Next?. Information Today. 23(4). pp. 1-2.

Ranganathan, S.R. (1931) The Five Laws of Library Science. Madras: Madras Library Association.

Samek, T. (2001). Library Ethics, Rights, and Values: Provocative Commentary on the Utility of Library Rhetoric. PNLA Quarterly. 65 (3). pp. 15-17 
REVIEWED AND AMENDED VERSION TO BE PUBLISHED IN JOURNAL OF LIBRARIANSHIP AND INFORM ATION SCIENCE IN M ARCH 2013, ISSUE 45 (1)

Smith, G.A (Ed). (2002). Christian Librarianship: Essays on the Integration of Faith and Profession. Jefferson: M cFarland.

Storey, C. (1993). Riding the tiger: Hong Kong librarians and the impact of 1997. Journal of Librarianship and Information Science. 25 (1). pp.23-32

Usherwood, R.C. (1980). Professional Values in Bureaucratic Structure. Library Review. 29. pp.8-14 